\title{
Participatory Planning Approach to Urban Conservation and Regeneration in Amphawa Community, Thailand
}

\author{
Wannasilpa Peerapun \\ Faculty of Architecture, \\ Chulalongkorn University Thailand \\ Wannasilpa.p@chula.ac.th
}

\begin{abstract}
The objective of this article is to examine participatory planning approach to urban conservation and regeneration in Amphawa Community, Thailand which includes a series of interrelated projects starting from 2000 until the present. Action research procedure is adopted and various public participation techniques are applied intensively throughout the planning process. In addition, "Amphawa Model", the community conservation and regeneration model, is developed to help direct all strategies and policies. Urban conservation and regeneration of Amphawa Community is very successful, making it an excellent case study for urban conservation and regeneration planning at the local level..
\end{abstract}

Keywords participatory planning, urban conservation and regeneration, Amphawa community

eISSN 2514-751X @ 2018. The Authors. Published for AMER ABRA CE-Bs by e-International Publishing House, Ltd., UK. This is an open-access article under the CC BY-NC-ND license (http://creativecommons.org/licenses/bync-nd/4.0/). Peer-review under responsibility of AMER (Association of Malaysian Environment-Behaviour Researchers), ABRA (Association of Behavioural Researchers on Asians) and $c E-B s$ (Centre for EnvironmentBehaviour Studies), Faculty of Architecture, Planning \& Surveying, Universiti Teknologi MARA, Malaysia.

DOI: https://doi.org/10.21834/aje-bs.v3i6.245 


\subsection{Introduction}

In the past, urban conservation planning usually dealt with the protection and restoration of historic monuments, significant buildings and their physical settings. Little attention was paid to social and economic development of the host community. Conservation policies and measures were too rigid and did not integrate with other local development plans, making them difficult to implement. The situation is much better today. This is due largely to the change in the principles of urban conservation. For example, a principle of the Washington Charter (ICOMOS, 2003) states that the conservation of historic towns and other historic urban areas should be an integral part of coherent policies of economic and social development and of urban and regional planning at every level. The charter also addresses that public participation and rigidity-avoidance are essential for the success of conservation programs. Today, the term "urban conservation and regeneration" is widely used to express the inclusion of economic and social dimensions in urban conservation planning and to reflect the significance of integrative planning.

Before the turn of the century, urban conservation movement in Thailand was very slow, especially at the local level. This was due largely to the lack of public interest and the difficulty of planning implementation. As a result, many traditional communities and settlements faded out while many others became deteriorated. Urban conservation and regeneration planning of Amphawa Community, Samut Songkhram Province, which started from 2000 until the present, has changed the situation dramatically. By exercising a new conservation direction and employing participatory planning approach, the community has been recovered from architectural deterioration as well as economic and social declines.

Amphawa Community is located in Samut Songkhram Province, about 18 kilometers from the estuary, and 80 kilometers west of Bangkok. It is a small municipality with approximately 5,000 residents. The community has along history as a water-based settlement dating back to Ayutthaya Period in the mid $17^{\text {th }}$ century. It was once the residence of King Rama I and was the birthplace of King Rama II. In the past, Amphawa was the biggest waterbased commercial center in Samut Songkhram Province. The old water-based settlement of the community consists of more than 300 units of wooden and masonry shop-houses and individual dwellings lining along Amphawa Canal. By the end of the $20^{\text {th }}$ century, with the advent of land transportation system, the community's original economic importance began to fade out. Amphawa Community became a small community with its housing mostly in a state of dilapidation, some of which was uninhabited. Little attention was paid to building maintenance and rehabilitation, causing the overall heritage values of the community to decline. Most of the community residents were the elderly and children. Young and active people migrated out of the area. Nonetheless, Amphawa still retains its identity as a waterbased community with beautiful temples, traditional row-houses and tropical fruit farms.

Urban conservation and regeneration planning in Amphawa Community was initiated as part of a research project on environmental conservation planning of rivers and canals in the western water basin of Thailand in 2000. The actual conservation and regeneration planning of Amphawa Community started in 2002 with "Pilot Project for Environmental Conservation and Development of Amphawa Community," followed by "Thailand Cultural 
Environment Project (TCEP)" from 2003 to 2005. Several buildings were renovated and Amphawa floating market was regenerated. Tourism in Amphawa Community grew rapidly during 2005 and 2006 when the Department of Industrial Promotion, Ministry of Industry, launched a national exhibition on Amphawa cultural heritage and products. From 2006 until the present, a number of row-houses have been restored by Chaipattana Foundation and local residents. Several activities have been undertaken by public and private agenciestopromote Amphawa cultural heritage and tourism. Amphawa Community is now a famous tourist destination in Thailand and a favorite destination for study trips of delegates from other local communities.

The successful story of Amphawa has propelled a new movement in urban conservation and regeneration in the nation. Several communities have begun to start their own conservation and regeneration projects. Thus, it is worthwhile to examine the participatory planning approach to Amphawa's urban conservation and regeneration, especially the tools and techniques for public participation and "Amphawa Model" which has been continuously refined. This should allow us to draw some useful findings for urban conservation and regeneration at the local level.

\subsection{Literature Review}

Urban conservation and regeneration in Amphawa Community employs participatory planning approach and action research process. According to ODPM (2003), participatory planning is a set of processes through which diverse groups and interests engage together in reaching for a consensus on a plan and its implementation. Participatory planning can be initiated by any of the parties and the forms it will take and the timetables are likely to be negotiated and agreed amongst participants. Since participation of relevance stakeholders are crucial to participatory planning, it is essential for the planner to analyze various groups of stakeholders and types of participation. A classic typology of eight levels of participation is developed by Arnstein (1969). The eight types, arranged in a ladder pattern with each rung corresponding to the extent of citizens' power in determining the end product, include manipulation, therapy, informing, consultation, placation, partnership, delegated power and citizen control. A more complete explanation of public participation is the "Public Participation Spectrum" developed by the International Association of Public Participation (2004). In this case, public participation is classified into five levels in association with goal, promise and techniques to consider. The levels of participation, ranging from the lowest to the highest, are as follows: informing, consultation, involvement, collaboration and empowerment. The planner can go further by matching suitable stakeholders with each level of participation. In this case, he can make use of a stakeholder analysis grid (WWF, 2005).

Action research is another useful tool for participatory planning. Generally speaking, action research means "learning by doing". According to O'Brien (2001), action research aims to contribute both to the practical concerns of people in an immediate problematic situation and to further the goals of social science simultaneously. Accomplishing a dual commitment - to study a system and concurrently to collaborate with members of the system in changing it in a desirable direction - requires an active collaboration of the researcher and 
the client. This requirement stresses the importance of co-learning as a primary aspect of the research process. Susman (1983) distinguishes five phases of an action research cycle. A problem is identified and relevant data are collected and analyzed. Several possible solutions are generated and the most appropriate one is selected and implemented. At the end of the cycle, the results of the intervention are analyzed and general findings are identified. The problem is re-assessed and the process of the next cycle begins.

Sustainable development is the ultimate goal for integrative urban conservation and regeneration planning. It was first mentioned in a report called "Our Common Future" and was defined as "development that meets the needs of the present without compromising the ability of future generations to meet their own needs". (World Commission on Environment and Development, 1987). The concept of sustainable development is widely accepted and expanded to include various dimensions of development. An interesting model developed by UNESCO (2005) comprises three stacked circles. The middle circle indicates the four dimensions of development

- $\quad$ natural, economic, social, and political aspects. The inner circle indicates four major issues associated with the four aspects. The outer layer indicates four means of development - conservation, appropriate development, peace in combination with equity and human rights, and democracy.

A complementary concept to sustainable development is "Sufficiency Economy Philosophy" initiated by H.M. King Bhumibol. According to Mongsawad (2007), it is a philosophy of "the middle path" that stresses three principles in all modes of conduct moderation, reasonableness and self- immunity. Knowledge and morality are two necessary conditions to achieve the three principles. Knowledge requires a thorough study of all available information and experience in order to make prudent decisions while morality stresses integrity, trustworthiness, honesty and diligence of individuals. Sufficiency Economy Philosophy guides people to live harmoniously and securely with a sustainable society and environment, allowing them to cope with all globalization impact.

\subsection{Methodology}

Urban conservation and regeneration planning in Amphawa Community is unique in terms of planning methodology. To integrate several projects introduced into the community by different agencies in various periods of time, action research, a "learning by doing" approach is adopted and applied. This approach allows the planner to add new issues into the new planning cycles quickly and easily. Five phases of action research cycle, modified from the one created by Susman (1983), include diagnosing, planning, action, evaluation and reflection. A stakeholder analysis grid which incorporates five levels of public participation introduced by the International Association of Public Participation (2004) is applied to identify and classify stakeholders into groups according to the level of participation. The analysis is verified regularly, especially at the beginning of a new project. Accordingly, a list of corresponding participation techniques is produced and verified. A sample of the list created in 2007 is shown in Table 1. 
Table 1: Amphawa's selected participation techniques in 2007

\begin{tabular}{|c|c|c|c|c|}
\hline \multicolumn{5}{|c|}{ Increasing level of public participation $\rightarrow$} \\
\hline INFRORM & GONSULT & INVOLVE & COLLABORATE & EMPOWER \\
\hline $\begin{array}{l}\text { - Publications } \\
\text { - Public address } \\
\text { system } \\
\text { - Newsletters } \\
\text { - Cultural } \\
\text { heritage atlas } \\
\text { - Exhibitions } \\
\text { - Open houses } \\
\text { - Information } \\
\text { center }\end{array}$ & $\begin{array}{l}\text { - Workshops } \\
\text { - Surveys } \\
\text { - Public meetings }\end{array}$ & $\begin{array}{l}\text { - Workshops } \\
\text { - Awareness } \\
\text { raising } \\
\text { - Children camps } \\
\text { - Student } \\
\text { volunteers } \\
\text { - Gultural heritage } \\
\text { survey } \\
\text { - Trainings } \\
\text { - Field trips } \\
\text { - Gultural festivals }\end{array}$ & $\begin{array}{l}\text { - Workshops } \\
\text { - Gitizen advisory } \\
\text { - Gonsensus } \\
\text { building } \\
\text { - Participatory } \\
\text { decision-making } \\
\text { - Demonstration } \\
\text { projects }\end{array}$ & $\begin{array}{l}\text { - Delegated } \\
\text { decisions }\end{array}$ \\
\hline
\end{tabular}

(Source: Peerapun, 2011)

Data requirements for urban conservation and regeneration in Amphawa Community are classified into 4 sustainable development dimensions which were identified during the initial workshop. They include natural and built environment, economic aspects, social and cultural aspects, and political aspects. Secondary data for all dimensions are collected from public statistical records, reports, official maps, websites and publications. Primary data relating to natural and built environment are collected mostly from field surveys. Additional information relating to this dimension is collected from in-depth interviews with local scholars and monks. Primary data relating to the other three aspects are collected mostly from in-depth interviews with community and sub-community leaders, local scholars and delegates from local occupational groups. Questionnaires are also used to collect social and economic data at household level. At the first stage of each new action research cycle (the diagnosing stage), the databases from the earlier cycle are revised and updated. New available data are also added to the databases to make them more complete and useful for the new research cycle.

\subsection{Results and Discussions}

Participatory planning approach to urban conservation and regeneration in Amphawa Community is unique in terms of methodology which is characterized by action research and integrative planning. Since the projects, funded by different agencies, may come at different periods of time and with different specific objectives that may not integrate with each other, an effective model is required to cope with the problem. "Amphawa Model", an integrative model for urban conservation and regeneration planning has been gradually developed. The original and simple model, based on sustainable development concept and comprised four dimensions similar to those of the UNESCO Model, was developed in 2002. The model was revised in 2005 to incorporate the community's core value of "Sufficiency Economy Philosophy". The inclusion of the philosophy into the model is very significant to the success of Amphawa's urban conservation and regeneration planning since it serves as the community's code of conduct in all stages of planning, especially when dealing with dispute and 
consensus building. The present model, revised in 2011, is shown in Figure1. In this version, "Sufficiency Economy Philosophy" which comprises three major principles in all modes of conduct - moderation, reasonableness and self-immunity - is placed at the center to express the community's core value. The four dimensions of sustainable development, adapted from the four dimensions of the UNESCO Model to reflect the essence of sustainable urban conservation and regeneration, are placed around the core value. They include the aspects of natural and built environment, economic aspects, social and cultural aspects, and political aspects. Relevance issues are then placed next to each dimension, allowing for adding new issues to the group easily. A circle, incorporating two important principles of urban conservation and regeneration addressed in the Washington Charter - integration and participation - is placed between the core value and the four dimensions to complete the model. This model is expected to be generalized across the nation. All local communities similar to Amphawa Community can the make great use of it in the future.

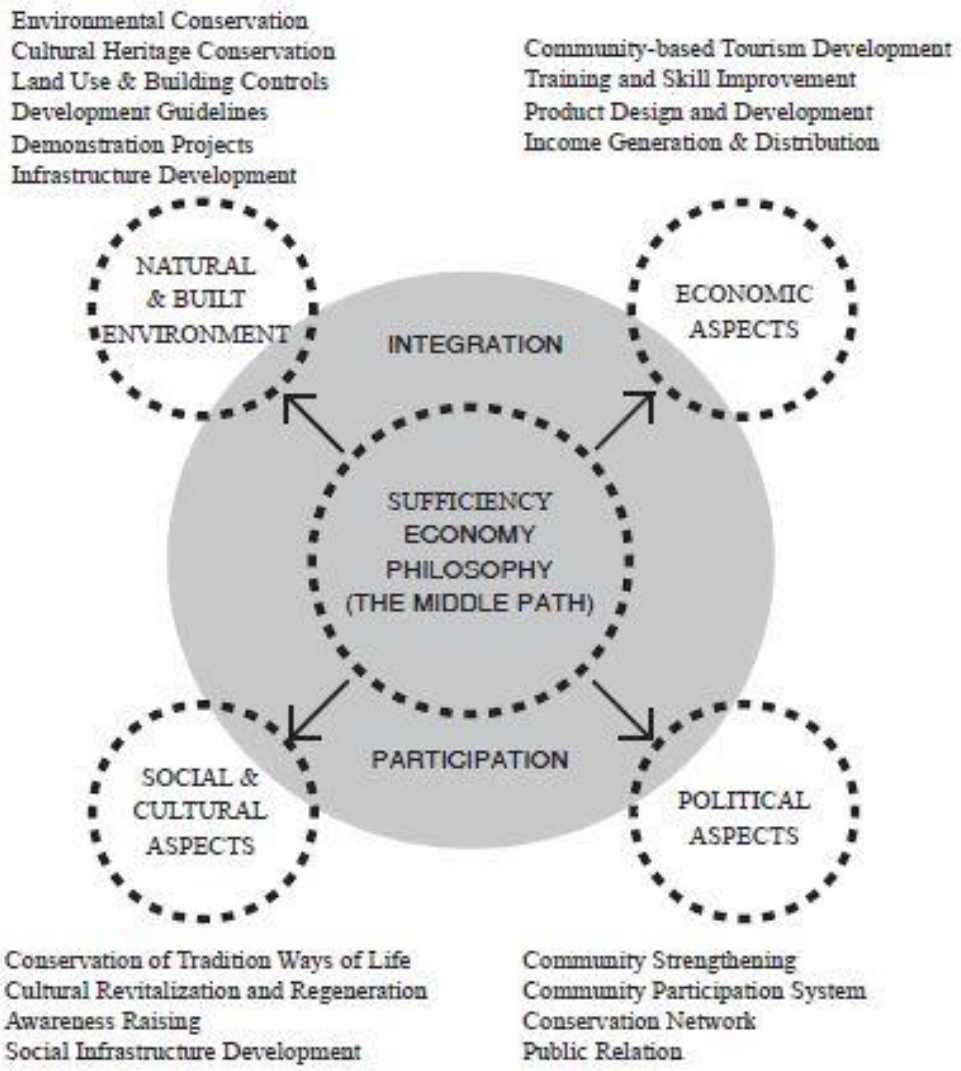

Figure 1: Amphawa conservation and regeneration model

(Source: Peerapun, 2011) 
In terms of planning process, action research approach is found to be very effective, especially when dealing with non-legal issues and policies. It is less effective when dealing with legal issues and policies which usually require a formal and more rigid procedure. In terms of participation techniques, publications are found to be the most important tools in the stage of informing while workshops are found to be very effective and multipurpose tool in the stages of consultation, involvement and collaboration. Delegated decision is the only effective way in the stage of empowerment because the community already has its ownneighborhood delegations. In terms of data requirements for urban conservation and regeneration, it is found that secondary data relating to the 4 dimensions of sustainable development were initially scarce but have increased gradually due to the availability of more reports and publications produced by relevant public agencies and educational institutes. Thus, fewer primary data are required to be collected today than in the past. However, revising and updating the databases and adding new data to them at the first stage of each new action research cycle are still essential because the community has changed rapidly since tourism development in 2004.

Awareness-raising is found to be the most significant issue in the case of Amphawa's conservation and regeneration planning. At the beginning, most residents believed that the old water-based settlementwas the symbol of poverty and community-based tourism on behalf of local cultural heritages was an impossible task. The planner had to put a lot of efforts and time to change negative attitudes towards cultural heritage values and tourism development. It is found that intensive awareness raising activities, exhibitions, and publications are effective participation techniques to cope with the problem. The planner's determination and patience are also required for solving the problem.

The achievement of urban conservation and regeneration in Amphawa Community is remarkable. In terms of cultural heritage conservation, a number of buildings along Amphawa Canal have been restored since the implementation of demonstration projects in 2004. In 2001, there were 351 unit of buildings along Amphawa Canal. About sixteen percent of them was uninhabited. In 2009, the number of the building units increased to 369 and none of them was uninhabited. Many of them were repaired and converted into tourist accommodations, restaurants and souvenir shops (Peerapun, 2010: 14, 17). In terms of tourism development, the number of tourists and accommodations in Samut Songkhram Province have increased rapidly since the regeneration of Amphawa Floating Market in 2004. During the period from 2004 to 2007, the number of tourists coming to the province increased from an insignificant number to 558,326 while the number of tourist accommodations increased from 218 to 1,620 rooms (Peerapun, and Silapacharanan, 2010: 18). The success of urban conservation and regeneration in Amphawa Community was acknowledged internationally when "Thailand Cultural Environment Project (TCEP)" and Amphawa Community won an honorable mention prize from UNESCO Asia-Pacific Awards for Heritage Conservation in 2008. The consequence of Amphawa conservation and regeneration is also impressive. The success story of Amphawa Community has paved way to a new movement in urban conservation and regeneration at the local level in Thailand. It has also encouraged many conservation planners to put more efforts in their conservation and regeneration projects. Amphawa Community has become a famous destination for study 
trips of delegates from many local communities. Some of them have started their own conservation and regeneration projects. Moreover, several floating markets have been regenerated and created in many places.

\subsection{Conclusion}

Participatory planning approach to urban conservation and regeneration in Amphawa Community is a unique and interesting case study, especially in terms of planning process and participation techniques. Action research is a powerful planning tool. In combination with appropriate participation techniques, it can produce satisfactory strategies and policies. The achievement of urban conservation and regeneration in Amphawa Community is remarkable in terms of building restoration and tourism development. The successful story of Amphawa Community has inspired many local communities to look back to their cultural heritage which has been neglected for a long time. It has also propelled a new movement in urban conservation and regeneration in the nation. A very significant output derived from the study is the model for urban conservation and regeneration at the local level, or "Amphawa Model," which integrates "Philosophy of Sufficiency Economy" with four dimensions of sustainable development and two conservation principles. Putting the philosophy at the heart of the model makes it more stable and directive. The principles of moderation, reasonableness and self-immunity are very helpful in developing issues, strategies and policies for urban conservation and regeneration in Amphawa Community. The determination and patience of the planner is another important condition for the success, especially when dealing with negative attitudes of local residents. Long-term planning and continuous work are also the keys for success. Thus, a partnership between the planner, the local community and all related agencies must be established.

\section{Acknowledgement}

The author gratefully acknowledge all participated agencies, especially the ONEP, DANIDA, Chaipattana Foundation, Department of Industrial Promotion (Ministry of Industry), Chulalongkorn University and the Faculty of Architecture (Chulalongkorn University) for their helps and financial supports. In addition, the author would like to thank the people and administrative staff of Amphawa Community for their cooperation and participation in all projects.

\section{References}

Arnstein, S. R. (1969). A Ladder of Citizen Participation. JAIP, 35(4), 216-224.

ICOMOS. (2003). Charters for the Conservation of Historic Towns and Urban Area (Washington Charter 1987). [WWW page]. URL http://www.international.icomos. org/charters/towns_e.htm

International Association of Public Participation. (2007). IAP2 Spectrum of Public Participation. [WWW page]. URL 
http://www.iap2.org/associations/4748/files/ spectrum.pdf

Mongsawad, P. (2009). Sufficiency Economy: A Contribution to Development Theory.

International Journal of Human and Social science, 4(2), 144-151.

O'Brien, R. (2001). Um exame da abordagem metodológica da pesquisa ação [An Overview of the Ethodological Approach of Action Research]. In Roberto Richardson (Ed.), Teoria e Prática da Pesquisa Ação [Theory and Practice of Action Research]. João Pessoa, Brazil: Universidade Federal da Paraíba. (English Version). [WWW page]. URL http://www. web.ca/ robrien/papers/arfinal.html

ODPM. (2003). Participatory Planning for Sustainable Communities: International Experience in Mediation, Negotiation and Engagement in Making Plans. London: Office of the Deputy Prime Minister.

Peerapun, W. (2009). Changes in the Use of Canalside Buildings on Amphawa Canal, Samut Songkhram Province: The Consequences of Conservation and Development Project from 2001 to 2009. Nahhara. Journal of Oriental Design and Planning, 5, 23-38.

Peerapun, W. (2011). Urban Conservation and Regeneration in Amphawa Community, Samut Songkhram Province. Manuscript.

Peerapun, W. and Silapacharanan, S. (2011). Conservation and Regeneration of Amphawa Community, Samut SongkhramProvince. SufficiencyEconomySeries2(pp.153-184). Bangkok: Chulalongkorn University Press.

Susman, G. I. (1983). Action Research: A Sociotechnical Systems Perspective.(pp. 95- 113). In G. Morgan (Ed.). Beyond Method: Strategies for Social Science Research (pp. 95-113). London: Sage Publications.

UNESCO. (2005). Four Dimensions of Sustainable Development. [WWW page]. URL http://www.unesco.org/education/tlsf/ TLSF/theme_a/mod04/uncom04t01s03.htm

World Commission on Environment and Development. (1987). Our Common Future. (The Brundtland Commission Report). Oxford: Oxford University Press.

WWF. (2005). Cross-Cutting Tool, Stakeholder Analysis. A resource to support the implementation of the WWF Standards of Conservation Project and Programme Management. [WWW page]. URL https://intranet.panda.org/ documents/folder. cfm?uFolderlD=60976 